\title{
Larvicidal effect of compounds isolated from Maerua siamensis (Capparidaceae) against Aedes aegypti (Diptera: Culicidae) larvae
}

\author{
Saksit Nobsathian ${ }^{1 *}$ (D) Vasakorn Bullangpoti ${ }^{2}$, Nutchaya Kumrungsee ${ }^{3}$, Natnicha Wongsa ${ }^{3}$ \\ and Dussadee Ruttanakum ${ }^{3}$
}

\begin{abstract}
Background: Dengue is a major problem for humanity. Most people use insecticides to eliminate larvae of Aedes aegypti, which requires heavy chemicals use that affects the environment and human health. Therefore, in this research, the focus was on the larvicidal efficacy of pure compounds from the leaves and twigs of Maerua siamensis against the larvae of $A$. aegypti.

Results: Larval mortality was observed after a 24-h exposure. The $1 \mathrm{H}$-indole-3 acetonitrile glycosides cappariloside $A$ and cappariloside $B$ and the triterpene lupeol showed strong larvicidal effects ( $24-h \mathrm{LC}_{50}=71.14,99.79$ and 133.03 ppm). After $48 \mathrm{~h}$, cappariloside B caused the most potential mortality with an $\mathrm{LC}_{50}$ of $1.56 \mathrm{ppm}$ and lupeol had the highest lethal concentration at $\mathrm{LC}_{50}=158.71 \mathrm{ppm}$. Additionally, consistency was observed between the toxicity tests and detoxification enzyme activity. Most compounds, except for lupeol and vanillin, reduce the activity of glutathione-s-transferase, whereas no significant differences were between control and treated groups for carboxylesterase.
\end{abstract}

Conclusions: Cappariloside A and cappariloside B are good potential larvicide agents. They showed larvicidal activity against Ae. aegypti larvae with $L C_{50}=71.14$ and 99.79 ppm at 24 and $48 \mathrm{~h}$, respectively.

Keywords: Maerua siamensis, Larvicidal agent, Aedes aegypti, Toxicity, Detoxification enzyme

\section{Background}

The yellow fever mosquito Aedes aegypti (Diptera: Culicidae) is a primary vector that causes dengue and dengue haemorrhagic fever [1]. In the 20th century, more than 1.8 billion people (more than $70 \%$ ) in 110 countries were at risk of dengue infection. In the past decade, because of the public health problems [2], most people use insecticides to eliminate the mosquitoes. However, the current use of insecticides has caused inhibition of cholinesterases and chromosomal aberrations in human peripheral leukocytes [3, 4]. Additionally, these insecticides also contaminate air, water, and soil in surrounding areas and therefore cause mortality to animals $[5,6]$. Thus, other

\footnotetext{
*Correspondence: saksit.nob@mahidol.ac.th

1 Nakhonsawan Campus, Mahidol University, Nakhonsawan 60130, Thailand

Full list of author information is available at the end of the article
}

insecticidal substances with lower toxicity to the environment than the ones in current use are urgently required [7].

Some plant compounds can eliminate larvae. The crude ethyl acetate extract of leaves of Acalypha fruticosa shows significant larvicidal activity with lethal concentration values $\mathrm{LC}_{50}$ and $\mathrm{LC}_{90}$ of 253.08 and $455.40 \mathrm{ppm}$, respectively [8]. The methanol extract from the leaves of Ocimum sanctum against fourth instar larvae of $A e$. aegypti has an $\mathrm{LC}_{50}$ value of $429.54 \mathrm{ppm}$ [9]. Deguelin and tephrosin, rotenoid types isolated from the seeds of Millettia dura show potent larvicidal activity with $\mathrm{LC}_{50}=1.6$ and $1.4 \mu \mathrm{g} / \mathrm{ml}$ at $24 \mathrm{~h}$, respectively [10]. The methanol extract of the leaves of Atalantia monophylla (Rutaceae) shows larvicidal activity against second stages Ae. aegypt $i$ with a lethal concentration $=0.002 \mathrm{mg} / \mathrm{l}$ [11] . 
Plants of Capparidaceae are found in tropical and subtropical regions of the world. Most plants of this family are found in Africa with 17 genera and 450 species [12]. Four genera are found in Thailand [13]: Capparis, Cleome, Crateva, and Maerua. All 90 species in the genus Maerua are found in tropical Asia, including the African continent. The crude extracts of plants in this genus have biological activities and ethnomedical applications. The aqueous root extract of $M$. oblongifolia is an anti-diabetic in rats [14]. The crude methanol extract of leaves of $M$. angolensis DC is active against Streptococcus pyogenes, Escherichia coli, and Neisseria gonorrhoeae [15]. The ethyl acetate fraction of the tuber parts of M. pseudopetalosa shows cytotoxic activity in brine shrimp larvae [16].

In this study, we focused on the isolation of larvicidal agents from Maerua siamensis (Kurt) Pax, the only species of the genus found in Thailand. The isolation of natural compounds from the leaves and twigs of this plant led to the separation of eight known compounds with promising insecticidal bioactivity.

\section{Methods}

\section{General experimental procedure}

Column chromatography (CC) used silica gel 60 (70-230 mesh, Merck Millipore, Darmstadt, Germany). Preparative thin-layer chromatography (Prep-TLC) used Kieselgel 60 PF254 (0.5 mm Merck Millipore, Darmstadt Germany). Benzenesulfonyl fluoride hydrochloride (AEBSF), EDTA, 1-chloro-2,4-dinitrobenzene (CDNB), glutathione-s-transferase, potassium phosphate buffer (pH 7.2), carboxylesterase and 4-nitrophenyl acetate (pNPA) were purchased from Sigma-Aldrich. The melting point was recorded on an electrothermal instrument. Optical rotations were determined on a JASCO DIP-370 digital polarimeter using a $50 \mathrm{~mm}$ microcell $(1 \mathrm{ml})$. UV spectra were measured in $\mathrm{EtOH}$ or $\mathrm{MeOH}$ with a JASCO 530 spectrometer, and IR spectra were recorded on a Perkin Elmer 2000. The ${ }^{1} \mathrm{H}-\mathrm{NMR},{ }^{13} \mathrm{C}-\mathrm{NMR}$, DEPT, and 2-D NMR spectra were recorded on a Bruker Ascend ${ }^{\mathrm{TM}}$ $400 \mathrm{MHz}$ or Bruker AVANCE $500 \mathrm{MHz}$. in $\mathrm{CDCl}_{3}$ using TMS as an internal standard, unless otherwise stated. Finally, HR-TOF-MS results were recorded on a Micromass model VQ-TOF2.

The leaves and twigs of $M$. siamensis were collected in Nakhonsawan Province, Thailand, in August 2015. A voucher specimen (BKF No. 180668) was deposited in and identified by the Forest Herbarium, Royal Forest Department in Bangkok.

Dried and finely powdered leaves and twigs $(1.70 \mathrm{~kg})$ of M. siamensis were percolated with $\mathrm{MeOH}$ at room temperature to produce a crude $\mathrm{MeOH}$ extract $(215.00 \mathrm{~g})$. After dissolution in $\mathrm{MeOH}$ : EtOAc (1:1) and solvent removal, a crude $\mathrm{MeOH}$ : EtOAc (1:1) soluble fraction
$(105.00 \mathrm{~g})$ was obtained. The active $\mathrm{MeOH}$ : EtOAc (1:1) soluble fraction was separated by $\mathrm{Si}$-gel $\mathrm{CC}\left(\mathrm{SiO}_{2}\right.$, $1.8 \mathrm{~kg}, \mathrm{CH}_{2} \mathrm{Cl}_{2}$-hexane and $\mathrm{MeOH}-\mathrm{CH}_{2} \mathrm{Cl}_{2}$ gradients) to give fractions $\mathrm{A}_{1}-\mathrm{A}_{5}$. Fraction $\mathrm{A}_{1}(2.57 \mathrm{~g})$ provided glochidone (3) (125.20 mg) after two consecutive Si-gel CCs $\left(\mathrm{CH}_{2} \mathrm{Cl}_{2}\right.$-hexane gradients), followed by recrystallisation from $\mathrm{MeOH}-\mathrm{CH}_{2} \mathrm{Cl}_{2}$. Fraction $\mathrm{A}_{3}(13.20 \mathrm{~g})$ afforded fractions $\mathrm{B}_{1}-\mathrm{B}_{7}$ after Si-gel $\mathrm{CC}$ (acetone-hexane, and $\mathrm{MeOH}$-acetone gradients). Fraction $\mathrm{B}_{2}(5.20 \mathrm{~g})$ gave fractions $\mathrm{C}_{1}-\mathrm{C}_{5}$ after Si-gel CC (EtOAc-hexane, and $\mathrm{MeOH}-\mathrm{EtOAc}$ gradients). Fraction $\mathrm{C}_{1}(1.52 \mathrm{~g})$ gave lupeol (4) $(121.20 \mathrm{mg})$ as white needles after recrystallisation from $\mathrm{MeOH}-\mathrm{CH}_{2} \mathrm{Cl}_{2}$. Fraction $\mathrm{C}_{2}(1.07 \mathrm{~g})$ yielded chrysoeriol (5) $(80.70 \mathrm{mg})$ after two consecutive CCs (1st CC: Si-gel, EtOAc-hexane gradient; 2nd CC: Sephadex $\mathrm{LH}-20, \mathrm{MeOH}$ ), followed by recrystallisation from ethanol. Fraction $\mathrm{C}_{3}(1.11 \mathrm{~g})$ yielded cappariloside A (1) (51.70 $\mathrm{mg}$ ) after separation by $\mathrm{CC}\left(\mathrm{CH}_{2} \mathrm{Cl}_{2}\right.$-hexane gradients), followed by recrystallisation from $\mathrm{MeOH}$. Fraction $\mathrm{B}_{3}(5.05 \mathrm{~g})$ provided cappariloside B (2) $(14.80 \mathrm{mg})$ after two consecutive Si-gel CCs (1st CC: EtOAc-hexane gradient; 2nd CC: acetone-hexane gradient), followed by prep-TLC ( $2 \% \mathrm{MeOH}-\mathrm{CH}_{2} \mathrm{Cl}_{2}$ as the eluent) and recrystallisation from EtOAc-hexane. Fraction $\mathrm{B}_{5}(2.15 \mathrm{~g})$ after two consecutive Si-gel CCs (1st CC: $\mathrm{CH}_{2} \mathrm{Cl}_{2}$-hexane and $\mathrm{CH}_{2} \mathrm{Cl}_{2}-\mathrm{MeOH}$ gradients; 2nd CC: EtOAc-hexane, and $\mathrm{MeOH}-\mathrm{EtOAc}$ gradients) gave fractions $\mathrm{D}_{1}-\mathrm{D}_{7}$. Fraction $\mathrm{D}_{6}(180.80 \mathrm{mg})$ provided cinnamic acid $(6)(17.30 \mathrm{mg})$ after recrystallisation from $\mathrm{MeOH}-\mathrm{CH}_{2} \mathrm{Cl}_{2}$. The residue $(98.20 \mathrm{mg}$ ) yielded 3,4-dimethoxybenzoic acid (7) $(21.20 \mathrm{mg})$ after recrystallisation from $\mathrm{CH}_{2} \mathrm{Cl}_{2}$-hexane. Fraction $\mathrm{B}_{6}(3.42 \mathrm{~g})$ was further purified by Si-gel $\mathrm{CC}$ (acetone-hexane gradient), followed by prep-TLC ( $2 \%$ $\mathrm{MeOH}-\mathrm{CH}_{2} \mathrm{Cl}_{2}$ ) to provide fractions $\mathrm{E}_{1}-\mathrm{E}_{4}$. Fraction $\mathrm{E}_{3}$ $(174.00 \mathrm{mg})$ gave vanillin $(8)(32.10 \mathrm{mg})$ following recrystallization from EtOAc. The structures of all pure compounds are shown in Fig. 1.

Cappariloside A (1) [17]: amorphous solid; m.p. 228.0$229.0{ }^{\circ} \mathrm{C}$; UV (MeOH) $\lambda_{\max }(\log \varepsilon) 267$ (4.79), 278 (4.61), 289 (4.14) nm.; IR (KBr disc) $v_{\max } 3525,3495,3400,3359$, 1625, 1590, 1508, 1170, 1084; HR-TOF-MS (ESI positive) $\mathrm{m} / \mathrm{z} 357.1069[\mathrm{M}+\mathrm{Na}]^{+}$(calcd. for $\mathrm{C}_{16} \mathrm{H}_{18} \mathrm{~N}_{2} \mathrm{O}_{6} \mathrm{Na}$, 357.1063).

Cappariloside B (2) [17]: amorphous solid; m.p. 230.1$231.3^{\circ} \mathrm{C}$; UV (MeOH) $\lambda_{\max }(\log \varepsilon) 272$ (4.00), 279 (3.88), 289 (4.12) nm.; IR (KBr disc) $v_{\max } 3390,2855,2255$, 1625, 1540, 1510, $1120 \mathrm{~cm}^{-1}$; HR-TOF-MS (ESI positive) $\mathrm{m} / \mathrm{z} 519.1589[\mathrm{M}+\mathrm{Na}]^{+}$(calcd. for $\mathrm{C}_{22} \mathrm{H}_{28} \mathrm{~N}_{2} \mathrm{O}_{11} \mathrm{Na}$, 519.1591).

Glochidone (3) [18]: colorless needles; m.p. 166.0$166.6{ }^{\circ} \mathrm{C}$; UV (EtOH) $\lambda_{\max }(\log \varepsilon) 228$ (3.96), 333 (1.73).; IR ( $\mathrm{KBr}$ disc) $v_{\max } 2945,2873,1662(\mathrm{C}=\mathrm{O}$ stretching of conjugated ketone), 1456, 1382, 1284, 1229, 1161, 1103, 
<smiles>N#CCc1c[nH]c2cccc(O[C@@H]3O[C@H](CO)[C@@H](O)[C@H](O)C3O)c12</smiles><smiles>N#CCc1c[nH]c2cccc(O[C@@H]3O[C@H](CO[C@H]4O[C@H](CO)[C@@H](O)[C@H](O)[C@H]4O)[C@@H](O)[C@H](O)[C@H]3O)c12</smiles><smiles>C=C(C)[C@@H]1CC[C@]2(C)CC[C@H]3[C@]4(C)CCC5C(C)(C)C(=O)C=C[C@]5(C)[C@H]4CC[C@]3(C)[C@H]12</smiles><smiles>C=C(C)[C@@H]1CC[C@]2(C)CC[C@]3(C)[C@@H](CCC4[C@@]5(C)CCC(O)C(C)(C)C5CC[C@]43C)[C@@H]12</smiles><smiles>COc1cc(-c2cc(=O)c3c(O)cc(O)cc3o2)ccc1O</smiles>

5<smiles>O=C(O)/C=C/c1ccccc1</smiles>

6<smiles>COc1ccc(C(=O)O)cc1OC</smiles><smiles>COc1cc(C=O)ccc1O</smiles>

7

8

Fig. 1 Compounds isolated from Maerua siamensis. All compounds were purified and their structures were elucidated based on spectroscopic data as described in the text

947, 888, $825 \mathrm{~cm}^{-1}$; HR-TOF-MS (ESI positive) $\mathrm{m} / \mathrm{z}$ 427.2044 $[\mathrm{M}+\mathrm{Na}]^{+}$(calcd. for $\mathrm{C}_{30} \mathrm{H}_{28} \mathrm{ONa}, 427.2038$ ); Optical rotation: $[\alpha]_{589}^{30}+68.6^{\circ}\left(c 0.1, \mathrm{CHCl}_{3}\right)$.

Lupeol (4) [19]: white powder; m.p. $212.4-213.0{ }^{\circ} \mathrm{C}$; IR $\left(\mathrm{CHCl}_{3}\right) v_{\max } 3486,2933,1640,1473,1384,1037$, $870 \mathrm{~cm}^{-1}$; HR-TOF-MS (ESI positive) $\mathrm{m} / \mathrm{z} 449.3750$ $[\mathrm{M}+\mathrm{Na}]^{+}$(calcd. for $\mathrm{C}_{30} \mathrm{H}_{50} \mathrm{ONa}, 449.3759$ ).

Chrysoeriol (5) [20]: yellow powder; m.p. 325.1$326.2{ }^{\circ} \mathrm{C}$; UV (MeOH) $\lambda_{\max }(\log \varepsilon) 269 \mathrm{~nm}$ (3.44), $340 \mathrm{~nm}$ (4.52) nm.; IR (KBr disc) 3350, 3088, 2925, 1777, 1719, 1655, 1607, 1561, 1506, $1256 \mathrm{~cm}^{-1}$; HR-TOFMS (ESI positive) $\mathrm{m} / \mathrm{z} 323.0540[\mathrm{M}+\mathrm{Na}]^{+}$(calcd. for $\mathrm{C}_{16} \mathrm{H}_{12} \mathrm{O}_{6} \mathrm{Na}, 323.0532$ ).
Cinnamic acid (6) [21]: white powder; m.p. 193.9$194.3{ }^{\circ} \mathrm{C}$; UV (MeOH) $\lambda_{\max }(\log \varepsilon) 272$ (2.85) nm.; IR (KBr disc) $v_{\max } 3448,1711,1638,1577,1551,1450 \mathrm{~cm}^{-1}$; HR-TOF-MS (ESI positive) showed $[\mathrm{M}+\mathrm{Na}]^{+} 171.0411$ $[\mathrm{M}+\mathrm{Na}]+$ (calcd. for $\left.\mathrm{C}_{9} \mathrm{H}_{8} \mathrm{O}_{2} \mathrm{Na}, 171.0422\right)$.

3,4-Dihydroxybenzoic acid (7) [22]: white powder; m.p. 130.9-131.0 ${ }^{\circ} \mathrm{C}$; UV (MeOH) $\lambda_{\max }(\log \varepsilon) 212$ (4.66), 268 (4.56) 313 (4.17) nm.; IR (KBr disc) $v_{\max } 3200,2839,1674$, $1603 \mathrm{~cm}^{-1}$; HR-TOF-MS (ESI positive) $\mathrm{m} / \mathrm{z} 177.0170$ $[\mathrm{M}+\mathrm{Na}]^{+}$(calcd. for $\left.\mathrm{C}_{7} \mathrm{H}_{6} \mathrm{O}_{4} \mathrm{Na}, 177.0164\right)$.

Vanillin (8) [23]: white powder; m.p. $81.0-83.2{ }^{\circ} \mathrm{C}$; $\mathrm{UV}(\mathrm{MeOH}) \lambda_{\max }(\log \varepsilon) 221$ (3.66), 271 (3.56) nm.; IR (KBr disc) $v_{\max } 3475,3444,3184,2733,2669 \mathrm{~cm}^{-1}$; 
HR-TOF-MS (ESI positive) showed $[\mathrm{M}+\mathrm{Na}]^{+} 175.0380$

$[\mathrm{M}+\mathrm{Na}]+\left(\right.$ calcd. for $\left.\mathrm{C}_{7} \mathrm{H}_{6} \mathrm{O}_{4} \mathrm{Na}, 175.0371\right)$.

\section{Mosquito strain}

Eggs of Ae. aegypti (Thailand laboratory strain) were received from the Ministry of Public Health, Thailand. Larvae were reared in 500-ml glass beakers containing water, fed a fish diet and maintained in our culture room at $28{ }^{\circ} \mathrm{C}$ and $70 \% \mathrm{RH}$ with a $14: 10 \mathrm{DL}$ photoperiod. The same conditions were used for the pupae. After emergence, adults were maintained in cages, in the same locale.

\section{Larvicidal toxicity assay}

The larvicidal bioassay against third instars of Ae. aegypti was modified from the WHO (1981) method under laboratory conditions at $28 \pm 1{ }^{\circ} \mathrm{C}$ and, $70 \%$ RH 14:10 DL photoperiod. Twenty-five larvae were placed in a small cup filled with $50 \mathrm{ml}$ of distilled water, to which $0.5 \mathrm{ml}$ of each extract dissolved in $0.5 \%$ acetone was added. The final concentration range for each treatment was from 125 to $1000 \mathrm{ppm}$ dissolved in acetone. For all concentrations, 15 replicates were used per concentration. In controls, $0.5 \mathrm{ml}$ of $0.5 \%$ acetone was used in each case. During the aqueous dispersion test, mosquito larvae were not provided with food. After 24 and $48 \mathrm{~h}$, mortality of the larvae in each treatment was recorded.

\section{Mode of action studied}

The larvae that survived the $\mathrm{LC}_{50}$ value treatment at $24 \mathrm{~h}$ of exposure were homogenised in $0.5 \mathrm{ml}$ of homogenised buffer [ $100 \mathrm{mM}$ phosphate buffer (pH 7.2) and $1 \%$ Triton $\mathrm{X}-100]$. The homogenate was centrifuged at $10,000 \times g$ for $15 \mathrm{~min}$ at $4{ }^{\circ} \mathrm{C}$, and the supernatant was used as the enzyme source.

To measure in vivo enzymes activities, $24 \mathrm{~h} \mathrm{LC}_{50}$ valuetreated larvae were homogenised in buffer A [100 mM phosphate buffer (pH 7.2) containing 1 M DTT, $100 \mathrm{mM}$ 4-(2-aminoethyl) benzenesulfonyl fluoride hydrochloride (AEBSF) and $0.5 \mathrm{M}$ EDTA]. The homogenate was centrifuged at $10,000 \times g$ for $5 \mathrm{~min}$ at $4{ }^{\circ} \mathrm{C}$, and the resultant supernatant was used for carboxylesterase and glutathione-s-transferase activity analyses.

Carboxylesterase (CE) activity was determined by the modified method of Kumrungsee [24]. Enzyme solution $50 \mu$ l, was mixed with 4-nitrophenyl acetate (pNPA) (10 $\mathrm{mM}$ in DMSO) and phosphate buffer $(50 \mathrm{mM}, \mathrm{pH}$ 7.4). Enzyme activity was measured at $410 \mathrm{~nm}$ and $37^{\circ} \mathrm{C}$ for $90 \mathrm{~s}$ with a microplate reader in the kinetic mode. The activity of $\mathrm{CE}$ was determined using the extinction coefficient of 176.4705 for pNPA.

The method for determining glutathione-s-transferase (GST) activity was according to Oppenoorth [25]. The reaction solution contained $100 \mu \mathrm{l}$ of enzyme solution, $50 \mathrm{mM}$ potassium phosphate buffer $(\mathrm{pH}$ 7.3) and $150 \mathrm{mM}$ 1-chloro-2,4-dinitrobenzene (CDNB). Optical density was recorded at intervals of $30 \mathrm{~s}$ for $3 \mathrm{~min}$ at $37{ }^{\circ} \mathrm{C}$ and $340 \mathrm{~nm}$ with a microplate reader. The GST activity was determined from the extinction coefficient of 0.0096 for CDNB.

Three biological replicates per treatment were analysed. The protein content of each fraction used as an enzyme source was determined by the Bradford method before measuring enzyme activities.

\section{Statistical analyses}

Probit analysis was used to calculate $\mathrm{LC}_{50}$ and $\mathrm{LC}_{90}$ values were determined using the STATPLUS program (version 2017). The range of detoxification enzyme activity from each treatment was compared using one-way analysis of variance (ANOVA).

\section{Results and discussion}

All pure compounds isolated from $M$. siamensis were identified by the comparison of their physical properties and spectroscopic data with those reported in the literature [17-23].

The larvicidal activities in the different periods of exposure to Ae. aegypti larvae are presented in Tables 1 and 2. Cappariloside A had the lowest lethal concentration with an $\mathrm{LC}_{50}$ of $71.14 \mathrm{ppm}$, and vanillin had the highest $\mathrm{LC}_{50}$ value at $=2846 \mathrm{ppm}$ at $24 \mathrm{~h}$ of exposure. After $48 \mathrm{~h}$, cappariloside $\mathrm{B}$ caused maximum mortality with an $\mathrm{LC}_{50}$ $1.56 \mathrm{ppm}$ and lupeol had the highest lethal concentration $\mathrm{LC}_{50}=158.71 \mathrm{ppm}$.

The effect of pure compounds on detoxification enzyme activity is shown in Table 3. Consistency was found between toxicity tests and detoxification enzyme activity. Most compounds except for lupeol and vanillin, reduce glutathione-s-transferase activity whereas, differences between the control and treated groups for carboxylesterase were not significant.

For triterpenes, glochidone and lupeol; lupeol $\left(\mathrm{LC}_{50}=133.03 \mathrm{ppm}\right)$ had better activity than betulinic acid [26] $\left(\mathrm{LC}_{50}=142 \mathrm{ppm}\right)$, but the activity of betulinic acid was better than that of glochidone $\left(\mathrm{LC}_{50}=382.34 \mathrm{ppm}\right)$ after $24 \mathrm{~h}$. No reports on the larvicidal activity of indole alkaloids are available. Cappariloside $\mathrm{A}$ and $\mathrm{B}$ were actively toxic $\left(\mathrm{LC}_{50}=71.14\right.$ and 99.79 ppm, respectively). Finally, cinnamic acid, 3,4dimethoxybenzoic and vanillin were weakly toxic. However, after $48 \mathrm{~h}$, cappariloside B, cinnamic acid, lupeol, cappariloside A, 3,4-dimethoxybenzoic acid and chrysoeriol were actively toxic $\left(\mathrm{LC}_{50}=1.56,22.76,58.87\right.$, $71.14,72.54$ and $77.55 \mathrm{ppm}$, respectively). Vanillin and 
Table 1 The $\mathrm{LC}_{50}$ and $\mathrm{LC}_{90}$ values (ppm) of compounds isolated from Maerua siamensis against 3rd instars of Aedes aegypti after $24 \mathrm{~h}$ of exposure

\begin{tabular}{|c|c|c|c|c|}
\hline Compounds & Slope & $\mathrm{LC}_{50} \pm \mathrm{SE}(\mathrm{ppm})$ & $\mathrm{LC}_{90} \pm \mathrm{SE}(\mathrm{ppm})$ & $x^{2}$ \\
\hline Cappariloside A & $0.89 \pm 0.37$ & $71.14 \pm 5.41 \mathrm{a}$ & $1980.51 \pm 182.71 a$ & 1.48 \\
\hline Cappariloside B & $1.14 \pm 0.21$ & $99.79 \pm 2.85 a$ & $1329.68 \pm 46.53 a$ & 0.6 \\
\hline Glochidone & $1.68 \pm 0.20$ & $382.34 \pm 35.95 a$ & $2210.21 \pm 56.45 a$ & 0.95 \\
\hline Lupeol & $1.28 \pm 0.21$ & $133.03 \pm 26.98 a$ & $1340.41 \pm 40.19 a$ & 0.39 \\
\hline Chrysoeriol & $1.12 \pm 0.46$ & $169.94 \pm 7.17 a$ & $2278.96 \pm 222.12 a$ & 4.53 \\
\hline Cinnamic acid & $0.81 \pm 0.19$ & $852.36 \pm 28.46 a$ & $32,231.97 \pm 7532.75 b$ & 0.41 \\
\hline 3,4-Dimethoxybenzoic acid & $0.61 \pm 0.19$ & $1032.87 \pm 66.07 b$ & $127,826.08 \pm 1213.11 \mathrm{c}$ & 0.22 \\
\hline Vanillin & $0.75 \pm 0.21$ & $2846.76 \pm 131.14 b$ & $144,759.28 \pm 17,673 c$ & 1.56 \\
\hline
\end{tabular}

Means within a column followed by the same letter of each time exposure are not significantly different at the 0.05 level by Tukey's test

Table 2 The $\mathrm{LC}_{50}$ and $\mathrm{LC}_{90}$ values (ppm) of compounds isolated from Maerua siamensis against 3rd instars of Aedes aegypti after $48 \mathrm{~h}$ of exposure

\begin{tabular}{|c|c|c|c|c|}
\hline Compounds & Slope & $\begin{array}{l}\mathrm{LC}_{50} \pm \mathrm{SE} \\
(\mathrm{ppm})\end{array}$ & $\mathrm{LC}_{90} \pm \mathrm{SE}(\mathrm{ppm})$ & $x^{2}$ \\
\hline $\begin{array}{l}\text { Capparilo- } \\
\text { side A }\end{array}$ & & & $32.71 \mathrm{a}$ & 1.48 \\
\hline & & & & 1.48 \\
\hline Glochidone & $1.57 \pm 0.46$ & $158.70 \pm 45.78 c$ & $1045.70 \pm 46.05 b$ & 3.62 \\
\hline Lupeol & $1.46 \pm 0.57$ & $58.87 \pm 4.02 \mathrm{a}$ & $443.32 \pm 15.54 c$ & 1.56 \\
\hline Chrysoeriol & $2.17 \pm 0.34$ & $77.55 \pm 15.72 \mathrm{a}$ & 302.46 & 0.25 \\
\hline $\begin{array}{l}\text { Cinnamic } \\
\text { acid }\end{array}$ & $0.70 \pm 0.22$ & $22.79 \pm 3.98 b$ & $1581.11 \pm 149.88 d$ & 0.48 \\
\hline $\begin{array}{l}\text { 3,4-Dimeth- } \\
\text { oxybenzoic } \\
\text { acid }\end{array}$ & $0.81 \pm 0.20$ & $72.54 \pm 3.06 a$ & $2732.78 \pm 216.78 e$ & 0.34 \\
\hline Vanillin & $0.98 \pm 0.20$ & $130.82 \pm 3.71 c$ & $2690.07 \pm 151.79 e$ & 0.78 \\
\hline
\end{tabular}

Means within a column followed by the same letter of each time exposure are not significantly different at the 0.05 level by Tukey's test glochidone were moderately toxic $\left(\mathrm{LC}_{50}=130.82\right.$ and $158.70 \mathrm{ppm}$, respectively).

Insects are well known to use detoxification enzyme to develop resistance to insecticides by increasing the level of enzymes. For example, Fonseca-González et al. [27] describe high levels of both cytochrome $\mathrm{P} 450$ monooxygenases and non-specific esterases in some of the fenitrothion and pyrethroid-resistant Ae. aegypti populations in Cambodia. Kasai et al. [28] also suggest that cytochrome P450 monooxygenases play an important role in resistance development for Ae. aegypti to pyrethroids. Additionally, Dusfour et al. [29] describe the regulation of cytochrome P450 genes and carboxylesterases in all three populations of Ae. aegypti from three French overseas territories worldwide. Thus, studies on the level of detoxification enzymes may be necessary to estimate trends in resistance to new compounds. However, in the present study, all compounds showed no significant effects on carboxylesterase enzyme (CEs) activity compared with controls. Compounds significantly inhibited

Table 3 Carboxylesterase activity (nM para phenyl acetate/mg protein/min) and glutathione-s-transferase activity (CDNB product/mg protein/min) of surviving 3rd instar Aedes aegypti after treatment with pure compounds from Maerua siamensis for $24 \mathrm{~h}$

\begin{tabular}{|c|c|c|c|c|}
\hline Compounds & Carboxylesterase activity $^{a}$ & $\mathrm{CF}^{\mathrm{b}}$ & Glutathione-s-transferase activity ${ }^{a}$ & $\mathrm{CF}^{\mathrm{b}}$ \\
\hline Control & $0.030 \pm 0.002 a$ & - & $0.321 \pm 0.121 f$ & - \\
\hline Cappariloside A & $0.031 \pm 0.001 a$ & 0.97 & $0.204 \pm 0.014 b$ & 1.57 \\
\hline Cappariloside B & $0.029 \pm 0.001 a$ & 1.03 & $0.156 \pm 0.005 a$ & 2.06 \\
\hline Glochidone & $0.031 \pm 0.001 a$ & 0.97 & $0.282 \pm 0.006 d$ & 1.14 \\
\hline Lupeol & $0.032 \pm 0.001 b$ & 0.94 & $0.343 \pm 0.023 \mathrm{~g}$ & 0.94 \\
\hline Chrysoeriol & $0.031 \pm 0.001 a$ & 0.97 & $0.280 \pm 0.009 d$ & 1.15 \\
\hline Cinnamic acid & $0.029 \pm 0.001 a$ & 1.03 & $0.207 \pm 0.002 c$ & 1.55 \\
\hline 3,4-Dimethoxybenzoic acid & $0.031 \pm 0.001 a$ & 0.97 & $0.291 \pm 0.076 \mathrm{e}$ & 1.10 \\
\hline Vanillin & $0.032 \pm 0.001 b$ & 0.94 & $0.493 \pm 0.289 h$ & 0.65 \\
\hline
\end{tabular}

\footnotetext{
${ }^{a}$ Means within a column followed by the same letter are not significantly different at the 0.05 level by Tukey's test
}

${ }^{\text {b }} \mathrm{CF}$ is a correction factor $=$ (enzyme activity of control)/(enzyme activity of treatment) 
glutathione-s-transferase activities between 1.10 - and 2.60 -fold, which could explain the mortality in mosquito larvae to the compounds.

\section{Conclusions}

In conclusion, cappariloside A and cappariloside B are good potential larvicide agents. They show larvicidal activity against Ae aegypti larvae with $\mathrm{LC}_{50}=71.14$ and $99.79 \mathrm{ppm}$ at 24 and $48 \mathrm{~h}$, respectively.

\section{Authors' contributions}

SN collected samples from Nakhonsawan Campus, Mahidol University, Nakhonsawan, Thailand. SN, VB, and NK designed the experiment. SN, NK, $N W$, and DR performed the experiments, analysed data and wrote the paper. $\mathrm{SN}, \mathrm{VB}, \mathrm{NK}$, and PM reviewed and checked all the details. All authors read and approved the final manuscript.

\section{Author details}

${ }^{1}$ Nakhonsawan Campus, Mahidol University, Nakhonsawan 60130, Thailand. ${ }^{2}$ Animal Toxicology and Physiology Speciality Research Unit, Zoology Department, Faculty of Science, Kasetsart University, Bangkok 10900, Thailand. ${ }^{3}$ Biology Department, Faculty of Science and Technology, Rajamangala University of Technology Thanyaburi, Pathumthani, Thailand.

\section{Acknowledgements}

This research project was supported by Mahidol University. We thanking the Nakhonsawan Campus Mahidol University. We thank Professor Patoomratana Tuchinda and Mr. Wisuwat Thongpichai for the advice and valuable discussion during this research.

\section{Competing interests}

The authors declare that they have no competing interests.

\section{Availability of data and materials}

All data are shown in Tables 1 and 2.

\section{Consent for publication}

This research has been confirmed for publication in the journal.

Ethics approval and consent to participate

Not applicable.

\section{Funding}

The Talent Management Fund for Mahidol University financially supported this work.

\section{Publisher's Note}

Springer Nature remains neutral with regard to jurisdictional claims in published maps and institutional affiliations.

Received: 24 November 2017 Accepted: 19 February 2018

Published online: 19 April 2018

\section{References}

1. Evenhuis NL, Samuel GM. 22 Familily Culicidae. In: Evenhuis NL, editor. Catalog of the Diptera of the Australasian and Oceanian Regions. Hawaii: Bishop Museum; 2007. p. 191-218 (Retrieved 4 Feb 2012).

2. Halstead SB. Global perspective on dengue research. Dengue Bull. 2000;24:77-82.

3. Seume FW, Casida JE, O'Brien RD. Effects of parathion and malathion separately and jointly upon rat esterases in vivo. Insectic Tox. 1960;8:43-7.

4. Sharma KA, Tiwari U, Gaur MS, Tiwari KW. Assessment of malathion and its effects on leukocytes in human blood samples. J Biomed Res. 2015:29:1-9.
5. Lenoir JS, Cahill TM, Sieber JN, Mcconnell LL, Fellers GM. Summertime transport of current use pesticides from the California Central Valley to Sierra Nevada Mountain Range, USA. Environ Tox Chem. 1999;18(12):2715-22.

6. Newhart K. Environmental fate of malathion. California Environmental Protection Agency Department of Pesticide Regulation Environmental Monitoring Branch. 2006;11:1-20.

7. Pluempanupat S, Kumrungsee N, Pluempanupat W, Ngamkitpinyo K, Chavasiri W, Bullangpoti V, et al. Laboratory evaluation of Dalbergia oliveri (Fabaceae: Fabales) extracts and isolated isoflavonoids on Aedes aegypti (Diptera: Culicidae) mosquitoes. Ind Crops Prod. 2013:44:653-8.

8. Pavunraj M, Ramesh V, Sakthivelkumar S, Veeramani V, Janarthanan S. Larvicidal and enzyme inhibitory effects of Acalypha fruticosa (F.) and Catharanthus roseus L (G) DON leaf extracts against Culex quinquefasciatus(say) (Diptera: Culicidae). Asian J Pharm Clin Res. 2017:10(3):213-20.

9. Mohamed AA. Larvicidal activity of Ocimum sanctum Linn. (Labiatae) against Aedes aegypti (L.) and Culex quinquefasciatus (Say). Parasitol Res. 2008;103:1451-3.

10. Abiy Y, Solomon D, Jacob OM, Matthias H, Martin GP. Effect of rotenoids from the seeds of Millettia dura on larvae of Aedes aegypti. Pest Manag Sci. 2003:59:1159-61.

11. Sivagnaname N, Kalyanasundaram M. Laboratory evaluation of methanolic extract of Atlantia monophylla (Family: Rutaceae) against immature stages of mosquitoes and non-target organisms. Mem Inst Oswaldo Cruz Rio de Janeiro. 2004;99(1):115-8.

12. Brummitt RK, Culham A, Seberg O, Heywood VH, editors. Flowering plant families of the world. Firefly Book: Ontario; 2007.

13. Chayamarit K, Capparaceae. Flora of Thailand. Vol. 5. No. 3. In: Larsen K, Smitinand T. editors. Bangkok: Chutima Press., 1991. p. 266-268.

14. Arulanandraj CN, Punithavani T, Indumathy S. Effect of murva (Maerua oblongifolia) on alloxan induced diabetes in rats. IJPSR. 2011;2(10):2754-6.

15. Ayo RG, Audu OT, Amupitan JO, Uwaiya E. Phytochemical screening and antimicrobial activity of three plants used in traditional medicine in Northern Nigeria. J Med Plants Res. 2013;7(5):191-7.

16. Manal Al, Bushra EEN. Cytotoxicity study on Maerua pseudopetalosa (Glig and Bened.) De Wolf tuber fractions. Afr J Plant Sci. 2015;9(12):490-7.

17. Ihsan C, Ayse K, Peter R. $1 \mathrm{H}$-Indole-3 acetonitrile glycosides from Capparis spinosa fruits. Phytochemistry. 1999;50:1205-8.

18. Ayer WA, Flanagan RJ, Reffstrup T. Metabolites of bird's nest fungi-19, new triterpenoid carboxylic acids from Cyathus striatus and Cyathus pygmaeus. Tetrahedron. 1984:40:2069-82.

19. Keawsa-ard S, Natakankitkul S, Liawruangrath S, Teerawutgulrag A, Trisuwan $\mathrm{K}$, Charoenying $\mathrm{P}$, et al. Anticancer and antibacterial activities of the isolated compounds from Solanum spirale Roxb. leaves. Chiang Mai. J Sci. 2012;39(3):445-54.

20. Amami SA, Maitland DJ, Soliman GA. Hepatoprotective activities of Shouwia thebaica webb. Bioorg Med Chem Lett. 2006;16:4624-8.

21. Hsieh TJ, Su CC, Chen CY, Liou CH, Lu LH. Using experimental studies and theoretical calculations to analyze the molecular mechanism of coumarin, $p$-hydroxybenzoic acid, and cinnamic acid. J Mol Struct. 2005;741:193-9.

22. Mrinmoy G, Prasenjit M, Tanaya G, Sumanta G, Basudeb B, Prasanta KM. 3,4-Dihydroxybenzoic acid isolated from the leaves of Ageratum conyzoides L. Eur J Biotechnol Biosci. 2013:1 (4):25-8.

23. Abdel-Mogib M, Ezmirly M, Basaif SA. Phytochemistry of Dipterygium glaucum and Capparis decidua. J Saudi Chem Soc. 2000:4:103-8.

24. Kumrungsee N, Pluempanupat W, Koul O, Bullangpoti V. Toxicity of essential oil compounds against diamondback moth, Plutella xylostella, and their impact on detoxification enzyme activities. J Pest Sci. 2014;87:721-9.

25. Oppenoorth FJ. Localisation of the acetylcholinesterase gene in the housefly, Musca domestica. Entomologia Experimentalis et Applicata. 1979;25:115-7.

26. Gloria NSDS, Frances TTT, Francine DS, Grace G, Alexandre AS, Simone CBG. Larvicidal activity of natural and modified triterpenoids against Aedes aegypti (Diptera: Culicidae). Pest Manag Sci. 2016;72:1183-7.

27. Fonseca-González I, Quiñones MA, Lenhart A, Brogdon WG. Insecticide resistance status of Aedes aegypti (L.) from Colombia. Pest Mang Sci. 2011;67(4):430-7. 
28. Kasai S, Komagata O, Itokawa K, Shono T, Ng LC, Kobayashi M, Tomita T. Mechanisms of pyrethroid resistance in the dengue mosquito vector, Aedes aegypti: target site insensitivity, penetration, and metabolism. PLoS Negl Trop Dis. 2014;8(6):1-23.
29. Dusfour I, Zorrilla P, Guidez A, Issaly J, Girod R, Guillaumot L, et al. Deltamethrin resistance mechanisms in Aedes aegypti populations from three French overseas territories worldwide. PLoS Negl Trop Dis. 2015;9(11):e0004226. https://doi.org/10.1371/journal.pntd.0004226.

Submit your manuscript to a SpringerOpen ${ }^{\circ}$ journal and benefit from:

- Convenient online submission

- Rigorous peer review

- Open access: articles freely available online

- High visibility within the field

- Retaining the copyright to your article

Submit your next manuscript at $\boldsymbol{\nabla}$ springeropen.com 